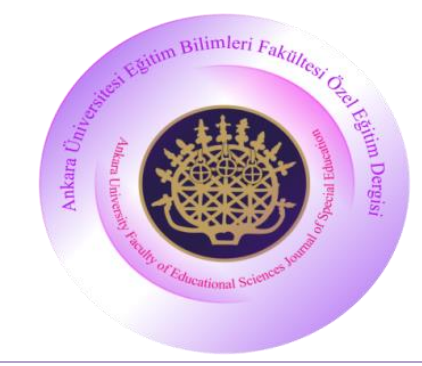

\section{Ankara Üniversitesi Eğitim Bilimleri Fakültesi Özel Eğitim Dergisi}

Yıl: 2017, Cilt: 18, No:1, Sayfa No: 89-108

DOI: 10.21565/ozelegitimdergisi.300060

\title{
Eş Zamanlı Olmayan Gelişimin Üstün Yetenekli Çocuklardaki Görünümü Üzerine Bir Örnek Olay Çalıșması
}

\author{
Adile Gülşah Saranlı* \\ TED Üniversitesi
}

\begin{abstract}
Öz
Üstün yetenekli çocuklar, belirli gelişim alanlarında yaşıtlarından daha üst seviyede performans gösteren çocuklar olarak tanımlanırlar ve gelişimsel olarak tüm alanlarda üstün oldukları önyargısı oldukça yaygındır. Hâlbuki üstün yetenekli bir çocuk bazı gelişimsel alanlarında yaşıtlarından üstün olup, diğerlerinde ortalama, hatta daha geride bir gelişim sergiliyor olabilir. Bu duruma "üstün yeteneklilerde görülen eş zamanlı olmayan gelişim" denmektedir. "Eş zamanlı olmayan gelişim" kavramı özel gereksinimli gruplarda oldukça önemsenmekte ve farklı çalışmalara konu olmaktadır. Buna karşın bu kavramın üstün yetenekliler grubundaki görünümü ve yapılabilecekler hakkında çok fazla derleme, örnek olay çalışması veya uygulama çalışması bulunmamaktadır. Bu çalışmada üstün yetenekli çocukları tanımlayan ve çoğunlukla yeterince bilgi sahibi olunmayan önemli kavramlardan olan eş zamanlı olmayan gelişim kavramı ayrıntılarıyla ele alınarak bu konudaki sorunlar ve çözüm yolları ortaya konmaya çalışılmıştır. Çalışmada 5 yaş 3 aylık Rüzgâr rumuzlu üstün potansiyelli çocuğun eş zamanlı olmayan gelişim örüntüsü örnek olay çalışması yöntemiyle sunulmuştur. Bu çalışmanın özellikle erken yaştaki üstün potansiyelli çocukların tanılanmaları, sosyo-duygusal gelişimlerinin desteklenmesi, ailelerin ve öğretmenlerin akademik ve sosyal anlamda çocuğun davranışlarını anlaması ve oluşabilecek sorunların baştan çözümlenebilmesinde pek çok yararlı bilgiyi sağlayacağı düşünülmektedir. Çalışmanın sonuç kısmında ortaya çıkan tabloya göre oluşturulabilecek erken müdahale yolları tartışlarak bu konularla ilgilenen öğretmenlere, ailelere ve uzmanlara öneriler getirilmiştir.
\end{abstract}

Anahtar sözcükler: Üstün potansiyel, üstün yetenek, eş zamanlı olmayan gelişim, erken müdahale, örnek olay çalışması.

\section{Önerilen Atıf Sekli}

Saranlı, A. G. (2017). Eş zamanlı olmayan gelişimin üstün yetenekli çocuklardaki görünümü üzerine bir örnek olay çalışması. Ankara Üniversitesi Ĕgitim Bilimleri Fakültesi Özel Eğitim Dergisi, 18(1), 89-108.

'Sorumlu Yazar: Yrd. Doç. Dr., TED Üniversitesi, Eğitim Fakültesi, Temel Eğitim Bölümü, Okul Öncesi Eğitimi Programı, Ankara, E-posta: gsaranli@gmail.com 
Üstün yetenekli çocuklar ile ortalama gelişim gösteren çocuklar arasında, erken çocukluk yaşlarından başlayarak dil, bilişsel, sosyal-duygusal ve psikomotor gelişimler açısından farklılıklar olduğu görülmektedir. Üstün yetenekli grubuna giren çocukların farklı gelişim alanlarında gösterdikleri bu hız ve yoğunluk genellikle ortalama gelişim gösteren çocuklardan çok daha ileridedir. Bu ileri olma durumu, çoğu anne baba, öğretmen ve uzmanı başlangıçta oldukça etkilemekte, sonrasında ise bu ileri gelişimle nasıl başa çıkılacağı ve nasıl yönlendirileceği konularında da endişeye düşürmektedir. Aile ve uzmanların aklını karıştıran üstün yetenek kavramı, onu tanımlayan çok önemli kavramlardan biri olan "eş zamanlı olmayan gelişim" kavramı ile birlikte ele alınmadığında, üstün yetenekli çocukları gerçekte olduklarından çok aşırı bir üstünlük ve mükemmellik örneği olarak algılamaya neden olabilmektedir. Özellikle bilişsel ve dil gelişim alanlarında yaşıtlarına göre gözle görülebilen ileri becerilere sahip olan üstün yetenekli çocuklara yönelik çevrelerinde oluşmuş olan algı, bu çocukların pek çok şeyi üst düzeyde yapmak konusunda becerikli olduklarıdır. Hâlbuki tüm gelişim alanlarında üstün seyredeceği varsayılan üstün yetenekli çocuğun gelişimi aslında düşünüldüğünden daha farklı bir görünüm ortaya koyabilmektedir. Gerçekte, üstün yetenekli olma potansiyelini taşıdığı düşünülen veya üstün yetenekli tanısı almış çocuklar her gelişim alanında üstün olmayabilirler ve bu durum aslında çok da normaldir. Bazı gelişim alanlarında yaşına göre üstün gelişim, bazılarında tipik gelişim bazılarında ise daha geriden gelen bir gelişim tablosu sergileyebilirler.

Örneğin, gelişim alanları açısından baktığımızda, bazılarının bilişsel becerileri oldukça ileride olabilir fakat sosyal-duygusal gelişim ve motor gelişimleri yaşlarıyla aynı düzeyde ya da yaşlarının gerisinde olabilir. Belirli beceriler açısından baktığımızda, üstün yetenekli olarak tanı almış bir çocuğun okumada mükemmel olup, matematikte zayıf olabildiğini, bir diğerinin yap-boz yapma veya makineler konusunda çok becerikli olup sözel gelişiminde ortalama bir beceri gösterdiğini görebiliriz. Bir başka örnek de bilgi dağarcıklarının çok gelişmiş̧ olmasına karşın sosyal alanlardaki yargılamalarının yaşları düzeyinde olması ya da geride kalmış olmasıdır. Üstün yetenekli çocukların farklı gelişim alanlarının farklı hızlarda ilerlemesiyle ilgili olan bu duruma "Eş Zamanlı Olmayan Gelişim" veya "Uyumsuz Gelişim" (Asynchronous Development) adı verilmektedir (Ataman, 2003; Kearney, 1992; Lovecky, 1998; Morelock ve Morrison, 1999; Porter, 1999; Silverman, 1994, 1997, 2002). Üstün yetenekli çocukların eş zamanlı olmayan gelişim gösterme durumunun oldukça yaygın olduğunun bilinmemesi veya bu kavramın tam olarak ne ifade ettiğinin anlaşılmamış olması, üstün yetenekli çocuklar için önemli bir risk unsuru oluşturmaktadır. Çoğu uzman, aile ve öğretmenin gözünden kaçabilen bu durum üstün yetenekli çocukların tanılanması, eğitimleri ve sosyal duygusal gelişimlerinde kısa, orta ve uzun vadede pek çok önemli soruna yol açabilmektedir. Bu sorunlar arasında; eş zamanlı olmayan gelişim gösteren bir üstün potansiyelli çocuğun geriden gelen bazı gelişim alanları sebebiyle tanılamaya bile dahil edilmemesi, geride olduğu becerilerin çevresindeki yetişkinler tarafindan daha önemli görülüp üstün yetenekli olduğu alanları gölgede bırakması, ya da tam tersi şekilde üstün olduğu konuların ön planda olması sebebiyle geriden gelen gelişimini desteklemek konusunda erken müdahalede bulunulmamasıyla ortaya çıkacak sorunlar sayılabilir (Silverman, 2002). Üstün yetenekli bir çocuğun hayatında olan aile, öğretmen, uzmanlar vb. kişilerin bu önemli kavramı bilerek hareket etmeleri, uzun vadede üstün yetenekli çocuğun hem akademik hem de sosyal-duygusal gelişimini koruyacak en önemli erken müdahale yöntemlerinden de biri olacaktır. Tüm bu riskler nedeniyle üstün yeteneklileri tanımlayan önemli özelliklerden olduğu vurgulanan bu kavrama ilişkin farkındalığın arttırılması ve nasıl anlaşılabileceğine ilişkin yöntemlerin somut ve tipik vakalar üzerinden gidilerek örneklendirilmesi gereklidir. Eş zamanlı olmayan gelişim kavramıyla ilgili farkındalığın yaratılması ve nasıl anlaşılabileceğine ilişkin örneklerin olması, eş zamanlı olmayan gelişimin anlaşılmasında hangi adımların izlenebileceği ve sonrasında yapılabilecek destek çalışmaları konusunda ailelere, öğretmenlere ve uzmanlara yol gösterici olacaktır. Çalışmanın yöntem kısmına geçmeden önce üstün yetenekli çocukların gelişimsel özellikleri ve eş zamanlı olmayan gelişimlerine ilişkin bilgiler aktarılacaktır.

\section{Üstün Yetenekli Çocukların Gelişimsel Özellikleri}

Üstün yetenekli çocukların genellikle göstermekte oldukları gelişimsel özelliklerle ilgili özellikle yurt dışında olmak üzere çok geniş bir alan yazın bulunmaktadır. Eş zamanlı olmayan gelişimle ilgili bilgilere geçmeden önce kısa da olsa bu grupta bulunan çocukların yaygın şekilde gözlemlenmiş olan özelliklerinden 
bahsetmek önemlidir. Üstün yetenekli çocukların tipik gelişim gösteren yaşıtlarıyla benzer olduğu kadar farklı gelişimsel özelliklerinin de olduğu pek çok alan uzmanı ve araştırmacı tarafından aktarılmıştır (Davis ve Rimm, 2011; Lovecky; 1993; Silverman, 2002; Webb, Gore, Amend ve Devries, 2007). Bununla birlikte alan yazında üstün yetenekli çocukların genel özellikleri başlığı altında aktarılan tüm özelliklerin her zaman tüm üstün yetenekli çocuklarda aynı çeşitlilikte ve yoğunlukta görülmeyebileceği, her zaman akılda tutulmalıdır. Çünkü üstün yeteneği tanılamamızı sağlayan çoğu özellik listesi çok fazla sayıda ve farklı alanda üstün yetenek sergileyen bireylerden toplanan bilgilerden oluşturulmuştur. Fakat bu listelerdeki özelliklerin hepsi aynı anda tek bir üstün yetenekli çocukta bulunmalıdır şeklinde bir yargıya gitmek de yanlış olacaktır. Bu ön bilgilerden sonra üstün yetenekli çocukları normal gelişim gösteren yaşıtlarından ayırt etmede bizlere yol gösterecek bazı tipik özelliklere geçiş yapılabilir. Bu özelliklere üstün yetenekli bireylerin karma yetenek düzeyinde bir grup olduğu her zaman için akılda tutularak bakıldığında faydaları daha fazla olacaktır. Bu özellikler kısaca; olağanüstü güçlü hafıza, aşırı merak, çok geniş ilgi alanı, hayal kurma ve yaratıcılık, espri yeteneği, deney yaparak öğrenme ve olayların nedenlerini anlama isteği, kendiyle veya diğerleriyle ilgili sabırsızlık, uzun dikkat süresi, karmaşık düşünebilme, sosyal-politik sorunlar ve haksızlıklarla ilgili endişe duyma, duyarlılıklar, gündüz rüyaları gibi şekillerde karşımıza çıkmaktadır (Davis ve Rimm, 2011; Lovecky; 1993; Silverman, 2002). Üstün yetenekli çocukların bebeklik dönemlerinden başlayarak olağan dışı dikkatli oldukları, hızlı öğrendikleri ve hızla düşünce oluşturabildikleri de alan yazında belirtilmektedir. Hafızalarının güçlü olduğu, çok miktarda bilgiyi hatırlayabildikleri görülmüştür. Dil gelişimi açısından yaşlarına göre çok geniş bir kelime dağarcığına sahip oldukları ve karmaşık cümle kullanımına meyilli oldukları sıklıkla aktarılmaktadır. Kelimelerle ilgili ayrıntıları, soyut düşünce ve metaforları kolaylıkla anlayabildikleri, sayılar ve bilmeceler içeren problemleri çözmekten büyük keyif aldıkları, okul öncesinde büyük ölçüde kendi kendine okuma ve yazmayı öğrendikleri de üstün yetenekli çocuklara ilişkin tespit edilmiş diğer özelliklerdendir (Webb ve diğ., 2007).

Sosyo-duygusal anlamda olağandışı duygusal derinliğe sahip olma, duyguları çok yoğun şekilde yaşama ve bu yoğun duygu deneyimi sonucunda güçlü duygusal tepkilerde bulunma ve aşırı duyarlılık da çoğu üstün yetenekli çocukta görülebilmektedir. Soyut, karmaşı, mantıksal ve öngörülü düşünme yetisi, erken yaşlarda beliren idealist yaklaşımlar ve adalet duygusu, sosyal ve politik konular ve haksızlıklar ile ilgili duyarlılık, üstün yetenekli çocukların belirgin özelliklerindendir. Bunlar dışında yoğun odaklanma ve zaman zaman kendi düşüncelerinde kaybolarak gündüz rüyaları görme de görülebilmektedir. Hem kendisinin hem de başka insanların yetersizlikleri veya yavaşlıkları ile ilgili sabırsız olma, temel becerileri daha hızlı ve daha az tekrar ile öğrenebilme, hatta öğretilenin ötesine geçerek araştırıcı sorular sorma üstün yetenekli çocuklarda sıklıkla görülmektedir. Geniş ilgi alanları, çok gelişmiş bir merak duygusu, sonu gelmeyen sorular sorma, birçok şeyi normalden farklı biçimlerde yapmaya duyulan ilgi de onları yaşıtlarından ayırt etmemizi sağlayan özelliklerindendir. Fikirleri alışılmadık veya kolayca görülmeyecek biçimlerde birleştirme yani rraksak düşünebilme, keskin ve bazen alışılmadık espri anlayışı, özellikle kelime oyunlarına ilgi duyma ile birlikte insanları ve eşyaları karmaşı oyunlar ve senaryolar ile organize etme isteği de bu grup çocukların çoğunluğunda görülme olasılı̆̆ yükssek olan özellikler listesinde yer almaktadır (Webb ve diğ., 2007).

\section{Üstün Yetenekli Çocuklarda Görülen Eş Zamanlı Olmayan Gelişim}

Üstün yetenekli çocuklar genellikle yetenekleri, gelişimsel performansları ve becerileri konusunda hem kendi içlerinde hem de diğer üstün yetenekli çocuklar ile aralarında farklılıklar gösterebilmektedirler. Üstün yeteneklilerde görülen bu farklı gelişime "eş zamanlı olmayan gelişim” adı verilmektedir. Bu terim, genellikle tipik gelişim gösteren benzer yaştaki bireylerde görülenve aynı yaştaki bilişsel, sosyal-duygusal ve fiziksel gelişim düzeyleri arasındaki uyumun görülmediği durumları tanımlar. Örneğin 6 yaşındaki bir çocuğun normalde göstermesi gereken bilişsel, sosyal-duygusal ve fiziksel gelişim aşağı yukarı tanımlanabilirken, bu yaştaki bir başka çocuğun fiziksel gelişiminin yaşından beklenenden geri olması, aynı zamanda bilişsel gelişiminin de yine yaşından beklenenden ileri olması eş zamanlı olmayan gelişimi anlamamızı kolaylaştırabilir. Terim ilk kez Columbus Grup tarafından kullanılmıştır ve çoğu zaman üstün yetenekli olmanın sonucu olarak değil, halihazırda 
üstün yetenekliliği tanımlayan önemli özelliklerden biri olarak anılmıştır. Columbus Grubun (1991) (akt., Morelock, 1996) üstün yeteneklilerde eş zamanlı olmayan gelişimimle ilgili en bilinen tanımlaması şu şekildedir;

"Eş zamanlı olmayan gelişim durumu, çocukların bilişsel yeteneklerinin kendi yaşlarından beklenenden daha hızlı ilerlediği belirgin ve tipik olmayan bir gelişim örüntüsüne karşılık gelmektedir. Eş zamanlı olmayan gelişim, ulaşılmış olan zihinsel, fiziksel, sosyal, duygusal ve yetenek seviyeleri arasında farklılık ve eşitsizlikler yaratır. Bunun sonucu olarak da üstün yetenekli çocuklar yaşıtları ile senkron farkı yaşarlar ve kültürlerinin yaş tabanlı beklentilerine uyamazlar."

Columbus grubu dışında uluslararası alan yazında üstün yeteneklileri tanımlayan önemli özelliklerden olan eş zamanlı olmayan gelişimden bahseden pek çok araştırmacı bulunmaktadır (Kearney, 1992; Lovecky, 1998; Morelock ve Morrison, 1999; Porter, 1999; Silverman, 1994, 1997, 2002). Üstün yetenekli çocukların zihinsel gelişimleri açısından akranlarından önde olmalarına karşın sosyo-duygusal ve/veya fiziksel gelişimde bu durumu gösteremeyebilecekleri durumunu somut örneklerle açıklayan kaynaklar da bulunmaktadır. Örneğin Amerikan Ulusal Üstün Yetenekliler Birliğinin (National Association of Gifted Children, NAGC) verdiği örneğe göre 6 yaşındaki bir çocuk 4. sınıf düzeyinde okuma ve problem çözebilme becerisine sahip olabilirken, motor becerilerindeki zayıflık sebebiyle eş zamanlı olmayan bir gelişim gösterebilmektedir. Bir başka örnek de 7 yaşındaki üstün yetenekli bir çocuğun, 6. sınıf düzeyinde okuma, 4. sınıf düzeyinde matematik becerisi gösterebilirken motor becerisinin 2. sınıf düzeyinde olabilmesi durumudur (NAGC, 2016).

Üstün yetenekli çocukların eş zamanlı olmayan gelişimleri, onları tipik gelişim gösteren çocuklardan daha da farklı ve heterojen bir grup yapmakta ve tüm üstün yetenekli çocukların bireysel özellikleriyle davranışları genellikle diğer üstün yetenekli çocuklardan da oldukça farklı olabilmektedir. Bu durum şaşırtıcı değildir. Çoğu anne-baba, öğretmen ve uzman, zihinsel gelişim düzeyinin daha az puanlar sergilediği ve özel eğitim gereksinimi nedeniyle bireyselleştirilmiş eğitim programlarına ihtiyaç hisseden çocukların gelişim özellikleri arasındaki farklılıkları daha kolay görebilmektedirler. İleri düzey zihinsel becerileri bulunan çocuklar arasındaki farklılıkları da aynı şekilde gelişimi gecikmiş olan çocuklardaki gibi, yani farklı gelişim alanlarının farklı seviyelerde gelişebildiği şeklinde düşündüğümüzde, üstün yetenekli çocukların eş zamanlı olmayan gelişimi çok daha kolay bir şekilde anlaşılabilecektir (Ataman, 2003; Silverman, 2002).

Özellikle okul öncesi dönemdeki üstün potansiyelli çocukları anlamaya ve tanılamaya çalışmak oldukça zordur. Çünkü bu yaş aralığındaki eş zamanlı olmayan gelişim daha da belirgindir. Bu gruptaki çocuklar genellikle tüm gelişim alanlarında olağandışı gelişim göstermek yerine belli bazı alanlarda üstün potansiyel gösterirler. Yaşına göre çok üst düzeyde görsel-uzamsal çıkarımlarda bulunan bir okul öncesi çocuğu, yüksek bir IQ skoruna veya gelişmiş bir dil becerisine sahip olmayabilir. Üstün yetenekli çocuklardaki eş zamanlı olmayan gelişimin çok farklı biçimlerde ortaya çıkabileceğine ilişkin çeşitli örnekler verilebilir. Bu farklı örneklerin çeşitlendirilmesi önemlidir, çünkü her üstün yetenekli çocuk bu durumu farklı şekilde yaşamaktadır. Eş zamanlı olmayan gelişim gösterme, çok fazla sayıdaki üstün yetenekli çocukta göze çarpan bir durum olduğundan çoğu uzman eş zamanlı olmayan gelişimin üstün yeteneği tanımlayan bir özellik olduğuna inanmaktadırlar (Adler, 2006; Ataman, 2003; Dağlıoğlu, 2004; Kokot, 1999; Strip ve Hirsch, 2000; Terassier, 1985).

Bir başka önemli nokta da üstün yetenekli çocukların ne kadar ileri derecede üstün yeteneğe sahiplerse, kendi içlerindeki gelişimin uyumu ile güçlü ve zayıf oldukları alanlar arasındaki farkın da o kadar fazla olabilmesidir (Silverman, 2002). Dolayısıyla sekiz yaşındaki üstün yetenekli bir çocuğun altıncı sınıf düzeyinde kitaplar okuyup, dördüncü sınıf düzeyindeki matematik problemlerini çözüp, üçüncü sınıf düzeyinde -ki bu gerçek yaş düzeyidir- ince motor becerilerine sahip olması alışılmadık bir durum değildir. Eş zamanlı olmayan gelişim gösteren bu tarz bir üstün yetenekli çocuk, bu durumu nedeniyle bireyselleştirilmiş bir eğitim programına ihtiyaç duyacaktır. Üstün yetenekli çocukların yetenek ve becerilerindeki geniş farklılıklar, onlara özel eğitim programları düzenlenmesini ve hangi sınıf düzeyinde eğitim görmeleri gerektiği konusunda düzenlemeler yapılmasını gerekli kılmaktadır. (Adler, 2006; Silverman, 2002; Terassier, 1985). 
Eş zamanlı olmayan gelişim kavramı Türkçe alan yazında da çeşitli araştırmacılar tarafından dile getirilmiştir. Örneğin Ataman’a göre (2003) üstün yetenekli pek çok çocuk eş zamanlı olmayan gelişimlerinden ötürü ilgi alanı doğrultusunda belli bir performans gösteren farklı gruptaki ve yaştaki çocuklarla arkadaşlık yapmayı seçebilirler. Örneğin, 10 yaşındaki bir çocuk kendisine uygun bir arkadaş olarak 18 yaşındaki bir çocuğu seçebilir. Bu durum ise zaman zaman 18 yaşındaki bir çocuğun karşı karşıya kaldığı sorunlarla karşılaşması durumunu doğurabilir. Örneğin, karşı cins ile ilişki, araba kullanma, madde kullanma gibi duygusal açıdan yaşına uygun olmayan problemlerle karşılaşmasına sebep olabilir.

Türkçe alan yazında eş zamanlı olmayan gelişim kavramının genellikle derleme tarzındaki çalışmalarla karşımıza çıktığı görülmektedir. Bu çalışmaların içeriklerine baktığımızda; üstün yeteneklilerde görülen eş zamanlı olmayan gelişim kavramının, öz düzenleme becerilerinin eş zamanlı olmayan gelişimi nasıl destekleyebileceği (Tortop ve Eker, 2014), üstün yeteneklilerin ailelerinin eş zamanlı olmayan gelişim sebebiyle yaşadıkları zorlukların neler olduğu (Karakuş, 2010), eş zamanlı olmayan gelişim kavramının temel tanımı (Kaya, 2015; Levent, 2014; Yıldırım, 2012), ve üstün yetenekli çocuklarda mükemmeliyetçiliği anlamaya çalışırken yardımcı bir bilgi kaynağı olarak eş zamanlı olmayan gelişimin yeri (Leana-Taşçılar, Özyaprak, Güçyeter, Kanlı ve Camcı Erdoğan, 2014) gibi konular çerçevesinde ele alındığı görülmüştür. Bu tarz çalışmaların alana getirdiği değerli katkılarla birlikte, eş zamanlı olmayan gelişimin hangi şekillerde görüldüğü, fark etme ve destekleme yollarına ilişkin detaylı olarak gerçekleştirilmiş bir örnek olay çalışmasına çalışmasına veya başlı başına eş zamanlı olmayan gelişim odaklı bir araştırmaya rastlanmamıştır. Eş zamanlı olmayan gelişim üstün yetenekli çocuklarda eğitimciler, aileler ve çocukla ilgilenen uzmanlar tarafindan özellikle göz önünde bulundurulması gereken bir konudur. Çünkü üstün yetenekli çocukları her alanda üstün olarak nitelendirerek, eş zamanlı olmayan gelişimlerini göz ardı etmek gelişimlerinin olumsuz yönde etkilenmesine neden olacaktır. Bu durum sadece engelli çocuklar için değil, üstün yetenekli çocuklar için de aynı dikkatle ele alınması ve özen gösterilmesi gereken bir konudur.

Buraya kadar aktarılan tüm bilgilerin ışı̆̆ında bu çalışmanın amacı, üstün yeteneklileri tanımamızı ve anlamamızı sağlayacak önemli özelliklerden olduğu vurgulanan üstün yeteneklilerdeki eş zamanlı olmayan gelişime ilişkin görünümü ortaya koyarak bu önemli kavramla ilgili farkındalığın arttırılması, üstün yetenekli bir çocukta bu durumun nasıl tespit edileceği ve nasıl desteklenebileceğine ilişkin yöntemlerin somut bir örnek olay üzerinden gidilerek örneklendirilmesidir. Eş zamanlı olmayan gelişim kavramıyla ilgili farkındalığın yaratılmasının, nasıl anlaşılabileceğine ve desteklenebileceğine ilişkin örneklerin olmasının üstün yeteneklilerdeki eş zamanlı olmayan gelişimin anlaşılmasında hangi adımların izlenebileceği konusunda ailelere, öğretmenlere ve uzmanlara yol gösterici olacağı düşünülmektedir. Bu amaca ulaşmayı sağlayacak en uygun yöntem olarak bu çalışmada örnek olay çalışması yöntemi seçilmiş ve bu konudaki tipik sayılabilecek bir örnek olay ele alınmıştır. Bu çalışmada sunulacak örnek olay çalışmasında eş zamanlı olmayan gelişim gösteren ve üstün potansiyelli olduğu düşünülen 5 yaş 3 aylık bir çocuğun bilişsel, dil, sosyal-duygusal gelişim alanlarının gözlemlenmesi, aile ve öğretmen görüşmeleri yapılması ve test uygulamaları sonucunda üstün yetenekli çocuklara özgü eş zamanlı olmayan gelişim gösterme durumunu hangi gelişim alanlarında, ne ölçüde ve yoğunlukta gösterdiği belirlenecek ve sonrasında bu duruma özgü gerçekleştirilebilecek bazı erken müdahale yöntemleri paylaşılacaktır.

\section{Yöntem}

\section{Çalıșmanın Deseni}

$\mathrm{Bu}$ çalışmada nitel metodoloji içinde yer alan ve sınırlı bir sistemin derinlemesine betimlenmesi ve incelenmesine olanak sağlayan "Örnek Olay/Vaka Çalışması”" deseni kullanılmıştır. Yin (2008, s. 18) araştırma süreci açısından örnek olay çalışmasını şöyle tanımlamaktadır: "Güncel bir olguyu gerçek hayattaki bağlamıyla özellikle olgu ile bağlam arasındaki sınırlar tam olarak belirgin değilse- inceleyen amprik bir araştırmadır." Stake (2005)'e göre, araştırmacı araştırmanın birimini, yani vakayı saptamaya odaklanmıştır. Wolcott (1992, s. 26) ise bunu bir strateji ya da yöntem olarak değil "saha odaklı bir araştırmanın nihai ürünü” olarak görmektedir. Miles ve Huberman (1994, s. 25) vakayı "sınırlı bir bağlamda daima gerçekleşen türde bir olgu" olarak düşünmektedir. Örnek olay, bir olgunun örneği olan tek bir kişi, bir program, bir grup, bir kurum, bir toplum ya da özel bir politika 
olabilir (Merriam, 2009). Bu çalışmada eş zamanlı olmayan gelişim gösteren üstün potansiyelli bir çocuğun değişik gözlem, görüşme ve ölçeklerle tespiti yapılmaya odaklanıldığından örnek olay çalışması deseni en uygun araştırma deseni olarak seçilmiştir. Örnek olay çalışmalarını türlere ayıran Stake'in (2005) tanımına göre burada bahsedilen çalışma "araçsal örnek olay çalışması" kategorisine girmektedir. Araçsal bir örnek olay çalışması bir konu hakkında fikir sağlamak ya da bir genellemeyi yeniden ele almak için yapılır. Vakanın kendisi ikincil öneme sahiptir, destekleyici bir rolü vardır ve başka bir şeyi anlamamızı kolaylaştırır (Stake, 2005, s. 437). Burada üstün yetenekli çocuklardaki eş zamanlı olmayan gelişim konusunu ele almak, bu konuda ilgili kişilerin farkındalığını arttırmak ve konunun örnekle anlaşılmasını kolaylaştırmak amacıyla Rüzgâr ve çevresindeki katılımcılar araştırmaya dâhil edilmiş̧lerdir. Çalışmada asıl amaç bireysel olarak çocuğun kendisinden çok eş zamanlı olmayan gelişim konusudur, bu sebeple araçsal örnek olay çalışması kategorisi bu çalışma için en uygun kategori olarak belirlenmiştir.

\section{Katılımeılar}

Örnek olay çalışmasında, araştırmak istediğiniz olgu özünde sınırlı değilse bir örnek olay değildir. Konunun ne derece sınırlı olduğunu değerlendirmek için kullanılan bir teknik, veri toplamanın nerede sona ereceğini sorgulamaktır. Yani görüşme yapılacak katılımcı sayısının bir sınırı olup olmadığına ya da gözlemlerin belirli bir zamanda sona erip ermeyeceğine bakmaktır. Teorik veya pratik olarak görüşülecek katılımcı sayısının ya da yapılacak gözlemlerin sonu yoksa olgunun bir örnek olay olmak için yeterince sınırlı olmadığı söylenebilir (Merriam, 2009). Bu çalışmadaki analiz sürecinde görüşme ve gözlem yapılacak ve ölçek uygulanacak katılımcılar; bir çocuk ve üç yetişkin olmak üzere 4 kişi ile sınırlandırılmıştır. Bu kişiler, çocuğun kendisi, annesi, babası ve okul öncesi öğretmenidir. Katılımcıların kimliklerini korumak için, bu araştırmada çocuk için 'Rüzgâr', annesi için 'İnci', babası için 'Kerim', okul öncesi öğretmeni için de 'Aysel' isimlerinin kullanılması uygun görülmüştür. Bu kısımda katılımcıları tanımlayan bilgilere yer verilecektir.

Rüzgâr, değerlendirme sırasında 5 yaş 3 aylıktır ve ailenin tek çocuğudur. Okumaya 3 yaşında başlamıştır. Annesi tarafından sessiz, içine kapanık, arkadaşı olmayan bir çocuk olarak tasvir edilmiştir. Çalışma gerçekleştirilirken Aile ve Sosyal Politikalar Bakanlığına bağlı özel bir anaokuluna devam etmektedir. Fiziksel anlamda güçlü ve yaşıtlarıyla benzer fiziksel özellikleri gösteren bir çocuktur. Rüzgâr'ın gıda alerjileri vardır ve bebekken kolik sorunu olmuştur. Ailesinin anlatımına göre Rüzgâr dil ve motor gelişimi ile ilgili gelişim adımlarını önden takip etmektedir. Örneğin ilk kelimelerini 8 aylıkken söylemiş, emeklemeden 10 aylıkken yürümeye başlamıştır. Çoğu zaman konuştuğu hayali bir arkadaşı vardır ve önemli bir zamanını resim yaparak ve yapboz çözerek geçirmektedir. Rüzgâr, anne babası tarafından bebekliğinde çok hareketli bir çocuk olarak tasvir edilmiştir. Bebekken günde yalnızca 6 ila 8 saat uyuduğu belirtilmiştir ve 9 aylıkken de yürümeye başladığı aktarılmıştır. Yürümeyi öğrendiği an itibariyle evde "çılgın" bir şekilde dolaştığı, her kapağı, her kapalı kutuyu açıp incelemeye meraklı olduğu belirtilmiştir. Dil ve motor gelişimi aşamalarından erken geçmiştir. Anne ve babası tarafından ileri derecede düşünme ve problem çözme yeteneğine sahip olduğu belirtilmiştir. Annesi, babası ve öğretmeni, Rüzgâr'ın bilim, uzay ve doğa temalarına takıntılı şekilde ilgi duyduğunu belirtmişlerdir.

Hem Rüzgâr'ın annesi İnci Hanım hem de babası Kerim Bey lise mezunu eğitim derecesine sahiptirler. Oturdukları ev kendi evleridir ve baba Kerim Beyin sosyal sigortası vardır. Rüzgâr'ın annesi İnci Hanım 24 yaşındadır. Dışarıda bir işte çalışmayıp, ev işleriyle ilgilenmektedir. Zaman zaman evde işlediği el işlerini çevredeki kermeslerde satarak ev giderlerine katkı sağlamaya çalışmaktadır. Zamanının çoğunluğunu evde geçirmektedir ve çok fazla sosyal destek aldığı bir çevresi yoktur. Kendi ailesi ve kardeşleri başka illerde oturduklarından ailesiyle senede birkaç kez görüşebilmektedir. İnci hanımın çocuğunun eğitimiyle ilgili destek alabildiği tek kişi çocuğunun okul öncesi kurumundaki öğretmeni Aysel Hanım'dır. Rüzgâr'ın babası Kerim Bey, 25 yaşındadır, teknikerdir ve aile dükkânında elektrik işleriyle ilgilenmektedir. Kerim Bey'in de İnci Hanım gibi iki kardeşi vardır. Kendisi kardeşlerin en büyüğüdür, aynı zamanda kazandığı para ile küçük kardeşini üniversitede okutmaktadır. Kerim Bey, elektrik işleriyle ilgilendiği işyerinde mesai saatlerinin dışında geçimlerini sağlamak üzere ekstra işlerde de çalışmaktadır. Yapılan görüşmelerde çocuğunun eğitimiyle annenin daha çok ilgilendiği, babanın çok fazla zaman ayıramadığı belirtilmiştir. 
Rüzgâr'ın okul öncesi öğretmeni Aysel Hanım 31 yaşındadır. Üniversitenin dört yıllık okul öncesi eğitimi bölümünden mezundur ve Çocuk Gelişimi alanında yüksek lisansını yapmaya devam etmektedir. Kendisi 4 senedir aynı okul öncesi kurumunda görev yapmaktadır. Son bir senedir kurumun idari görevlerini de yapmaya başlamıştır. Rüzgâr'ın farklı gelişimini fark edip aileyi de bu konuda yönlendiren ilk kişidir. Yapılan görüşmelerde kendisinin de aynı yaşta bir oğlu olduğunu ve onda da farklı gelişimsel özellikler gördüğü için üstün yetenekliler konusuna normalden fazla ilgi duyduğunu belirtmiştir.

\section{Veri Toplama Araçları}

Bu araştırmada üstün potansiyelli 5 yaş 3 aylık bir çocuğun eş zamanlı olmayan gelişim örüntüsünü ortaya koyabilmek adına çeşitli veri toplama araçları kullanılmıştır. Örnek olay çalışması desenine veri toplama araçları açısından bakıldığında, araştırmacı tek bir olguya ya da varlığa (vaka) yoğunlaşarak o olguya ilişkin önemli faktörlerin etkileşimini ortaya çıkartmayı amaçlamaktadır. Dolayısıyla örnek olay çalışması analizinde veri toplama ya da veri analizi için tek bir yönteme bağlı kalmak gerekmemektedir. Her ne kadar bazı teknikler diğerlerine göre daha fazla kullanılsa da anketten yüz yüze görüşmeye kadar veri toplama yöntemlerinin tümü örnek olay çalışmasında kullanılabilir (Merriam, 2009). Cresswell (2007, s.73)'e göre "örnek olay çalışması, araştırmacının sınırlı bir ya da birkaç sistemi (vakalar), pek çok kaynaktan (gözlemler, yüz yüze görüşmeler, görsel işitsel malzemeler, doküman ve raporlar) topladığı ayrıntılı ve derinlemesine verileri kullanarak zaman içinde keşfettiği ve vakayı betimleyerek vakayla ilgili temaları raporlaştırdı̆̆ı" bir yaklaşımdır. Bu bilgiler doğrultusunda bu çalışmada birden çok kaynaktan veri toplama yoluna gidilmiştir. Bu seçimin bir başka nedeni de alan yazında genelde üstün yetenekli çocukların gelişimlerinin anlaşılması ve tespit edilmesinde kullanılan araçların da örnek olay çalışmasında kullanılan araçlarla benzerlik göstermesidir ve bu ikinci sebeple de kullandığımız araştırma desenini destekler niteliktedir. Üstün yeteneğin anlaşılmasında hangi yöntemlerin, hangi sırada kullanıldığına kısaca baktığımızda da genellikle öncelikle anne babalar ve öğretmenlerden edinilen bilgilerin değerlendirilmesi, doğrudan çocuğun davranışlarının gözlemlenmesi, çocuğun yaratıcı ürünlerinin gözden geçirilmesi ve standart zekâ ve gelişim testlerinin uygulanması (Johnsen, 2005) şeklinde bir süreç ve veri toplama kaynağı kullanımı olduğu gözlemlenmektedir. Bu açıklamalara uygun olarak bu çalışmada kullanılan veri toplama yöntemleri temel olarak görüşmeler, gözlemler ve ölçek, test ve kontrol listeleri şeklinde organize edilmiştir. Veri toplama yöntemlerine ilişkin daha ayrıntılı bilgiler, aşağıda alt başlıklar halinde verilmiştir.

Görüş̧meler. Süreçte öncelikle Rüzgâr'ın annesi ve babasıyla yarı yapılandırılmış görüşmeler gerçekleş̧irilmiştir. Görüşmelerde yarı yapılandırılmış sorular kullanılmış olmasının nedeni, ailenin Rüzgâr'a ilişkin hem belli gelişim dönemlerindeki durumunu anlatabilmesine olanak verecek yapıdaki soruları sorabilmek hem de görüşme sırasında aileden alınabilecek her türlü ekstra bilgiye/anekdota uygun ortamı sağlayacak esnekliğe sahip olabilmektir. Anne babalar özellikle okul öncesi dönem çocuklarının yetenekleri ve davranışlarıyla ilgili çok zengin sözel ve anekdota dayalı bilgiler verebilirler. Bu görüşmeler sırasında anne ve babasına, Rüzgâr'ın doğumundan itibaren gözlemledikleri gelişimsel farklılıklar sorulmuştur. Bebeklik döneminin önemli gelişimsel dönüm noktalarından olan emekleme, yürüme, konuşma gibi çeşitli gelişim noktalarına ne zaman ve nasıl geldiği sorulmuştur. Bunlar dışında sosyal-duygusal gelişimi, motor gelişimi, dil ve zihinsel gelişimine ışık tutacak yarı yapılandırılmış sorular vasıtasıyla aileden bilgiler toplanmıştır. Tüm bu sorular, çocuk gelişimi alan yazınında normal gelişim gösteren çocukların dört gelişim alanında (zihinsel, dil, sosyo-duygusal ve motor) belli yaşlarda gözlenmesi beklenen davranışların Rüzgâr'da hangi zamanda ve ne şekilde gözlemlendiği odağına dayalı olarak yapılandırılmıştır. Görüşme formunda her bir gelişim alanı için kritik olan dönemlere ilişkin toplam 16 soru yer almıştır. Sorulardan bazı örnekler şu şekildedir; "Rüzgâr ne zaman kendi başına oturdu? Rüzgâr ne zaman konuştu?" vb. Bunun dışında Rüzgâr'ın okul öncesi öğretmeni Aysel hanımla da yarı yapılandırılmış görüşmeler yapılmıştır. Öğretmeniyle de Rüzgâr'ın okul ortamına uyumu, arkadaşlık ilişkileri, bireysel ve grup ortamlarındaki davranışları ve sosyal-duygusal gelişimi, motor gelişimi, dil ve zihinsel gelişimiyle iliş̧kili soruların yöneltildiği görüşmeler yapılmıştır.

Rüzgâr'ın ailesi ile gerçekleştirilen görüşmeler 2015 senesi içerisinde Mart, Nisan ve Mayıs ayları boyunca gerçekleştirilmiştir. Bu süreç içerisinde anne ve babasının katılımıyla 5 görüş̧me yapılmış, her bir 
görüşme $45 \mathrm{dk}$. ile $65 \mathrm{dk}$. arasında sürmüştür. Aile ile yapılan görüşmeler sırasında özellikle Rüzgâr'ın görüşmede bulunmaması rica edilmiştir ve aile de bu konuda uyumlu davranmıştır. Rüzgâr'ın ailesi çocuklarındaki erken gelişmeleri gözlemleyerek kendiliklerinden danışmanlık istemiş bir aile değildir. Dolayısıyla direkt olarak çocuklarının üstün yetenekli olma potansiyellerini fark ederek çocuklarını aday göstermek yerine çocuklarının öğretmeni tarafından yönlendirilmişlerdir. İlk görüşme sonrasında aileden üstün yetenekli çocukların tipik özelliklerini içeren bir dereceleme ölçeğini doldurmaları istenmiştir. Bu kontrol listesinin sonuçlarına göre Rüzgâr'ın gelişimsel olarak farklılıkları tüm bu süreç sırasında daha da belirginleşmeye başlayınca bu sefer aileyle bireysel görüşmeler yapılmaya devam edilmiştir. Bu görüşmeler sırasında çocuklarının belli becerilerde ilerleme kaydedip kaydetmediği sorularak daha derin bilgiler elde edilmiştir. Bu görüşmeler sırasında aileden Rüzgâr'ın başarılarını ve ilgilerini tanımlayan anekdota dayalı bilgiler edinilmiştir. Benzer şekilde okul öncesi öğretmeninden alınan bilgiler de Rüzgâr'ın gelişimsel durumunun netleştirilmesinde oldukça etkili olmuş, önemli bilgiler vermiştir.

Gözlemler. Bu araştırmada araştırmacı tarafından 5 yaş 3 aylık Rüzgâr'ın test uygulamaları sırasındaki genel davranışlarına ilişkin gözlemleri yapılmıștır. Bu gözlemler her bir testin uygulama süresi ile sınırlı şekilde gerçekleştirilmiştir Örneğin Denver Gelişim Tarama Testi sırasında test süresi öncesi ve sonrası dâhil olmak üzere toplam gözlem süresi $25 \mathrm{dk}$. olarak gerçekleştirilmiştir. Gözlem sonuçları, test uygulamaları sırasında gözlemlenebilecek davranışlar olan dikkat süresi, testörle iletişimi, test uygulama sürecindeki uyumu gibi başlıklar altında toplanan bir gözlem kayıt formuna işlenmiştir. Test uygulamaları ve gözlemi Rüzgâr'ın devam ettiği anaokulundaki uyaranlardan mümkün olduğunca arındırılmış okul psikoloğunun odasında gerçekleştirilmiştir. Ailenin Rüzgârın genel davranışlarına ilişkin ev ortamındaki davranış gözlemleri de zihinsel, dil, sosyal-duygusal ve motor gelişim alanları başlıkları altında kaydedilmiştir. Aynı şekilde Rüzgâr'ın öğretmeninden de sınıf ortamında ve teneffüs zamanlarında hem sınıf içindeki performansı hem de sınıf içi ve dışındaki sosyal ilişkileri başlıkları altında doğal gözlem yapması istenmiş, daha sonra bu bilgiler birebir görüşmelerle öğretmeninden alınmıştır.

Ölçek ve testler. Bu analizde kullanılan bir başka aşama da kontrol listesi, ölçek ve test uygulamaları olmuştur. Kontrol listesi dışında tüm testler aile ve öğretmen görüşmeleri sonrasında uygulanmıştır. Bu araştırma için gerçekleştirilen ölçek, test ve kontrol listelerine ilişkin kısa bilgiler aşağıda sunulmuştur.

Üstün Yetenek Derecelendirme Ölçeği. Rüzgârla ilgili öncelikle uygulanan araç, hem öğretmenine hem de anne babasına verilen derecelendirme ölçeği idi.. Rüzgâr'ın anne ve babasıyla yapılan ilk görüşme sonrasında aileye evde baş başa doldurmaları amacıyla verildi ve bir hafta sonraki ikinci görüşmeye doldurulmuş şekilde getirmeleri rica edildi. Hem aile için hem de öğretmen için uygulanan derecelendirme ölçeği, Davis Joint Unified School District tarafından geliştirilmiş olan öğretmen ve aile aday gösterme formuna dayalı olarak araştırmacı tarafindan Davis, Rimm ve Siegle (2011)'den uyarlanmıştır. Öğretmen dereceleme ölçeğinde toplam 36 madde bulunmaktadır. Bu maddeler kişisel (5 madde), ifade edici dil (4 madde), düşünme süreçleri (9 madde), üretkenlik ve çıktı (7 madde) akademik başarı ( 2 madde), liderlik (3) ve diğer özellikler (6 madde) başlıkları altında toplanmıştır ve maddeler "Çoğunlukla, Bazen ve Çok Az" şeklinde değerlendirilmektedir. Aile listesinde ise aynı başlıklarda toplam 24 madde yer almaktadır ve öğretmen formundaki gibi ailenin de bu maddeleri kendi çocuklarını düşünerek aynı derecelendirmeyi kullanarak işaretlemeleri istenmektedir.

Denver II Gelişimsel Tarama Testi. Çocuklarda gelişmenin izlenmesi, normalden sapmaların erken tanınabilmesi için gelişimsel tarama testlerinin düzenli olarak kullanılması gereklidir. Denver II Gelişimsel Tarama Testi, performansa dayalı bir testtir ve çocuğa bireysel olarak uygulanmaktadır. Test, asıl olarak 0-6 yaş arasındaki çocuklarda gelişimsel riskleri belirlemeyi amaçlamaktadır. Denver Gelişimsel Tarama Testi (Denver II) çocuklarda bulunabilecek gelişimsel sorunları yakalamada sağlık personeline yardımcı olması amacıyla ilk kez 1967 yılında yayınlanmıştır. İlk yayınlanışından sonra birçok ülkede uyarlanarak ve standardize edilerek kullanılmıştır. Bu test, 1981 yılında Türk kültürüne uyarlanan ve standardize edilen Denver Gelişimsel Tarama Testi'nin (DGTT) revize edilmiş biçimidir. Denver II, çocuğun işlevlerdeki becerisini yaşıtları ile karşılaştırır. Zekâ testi değil, gelişim tarama testidir ve gelecekteki zihinsel veya uyumsal yeteneği tahmin etmede kullanılamaz. 
Bununla birlikte çocuğun yaşıtlarına göre durumunu ortaya koyduğundan üstün potansiyelli çocukları tanımamızda ve anlamamızda yardımcı olabilecek değerli bir bilgi kaynağıdır. Denver II Gelişim Tarama Testinde, Kişisel-Sosyal (insanlarla iletişim kurma, bireysel gereksinimlerini karşılayabilme), İnce motor-uyumsal (el-göz koordinasyonu, cisimleri kullanabilme, sorun çözme), Dil (işitme, anlama, dili kullanma) ve Kaba motor (oturma, yürüme, zıplama ve genel olarak koordinasyon yeteneği) alanlarında sorular bulunmaktadır (Denver, 2016).

Peabody Resim-Kelime Testi. Çocuklardaki alıcı dil gelişimini ortaya koymak amacıyla geliştirilmiştir. Testin orjinal adı "Peabody Picture-Vocabulary Test"tir. İlk defa Dunn tarafindan 1959 senesinde geliştirilmiştir. Türkçeye uyarlama çalışması ise Katz, Önen, Demir, Uzunkaya ve Uludağ tarafından oluşturulmuş bir ekip sayesinde 1974 yılında gerçekleştirilmiştir (Öner, 1997). Testin güvenirliği 0.71 ile 0.81 arasında, test tekrar güvenirliği ise 0.52 ve 0.90 arasında değişmektedir (Özgüven, 1998). Bu test genel olarak iki ile 12 yaş arasındaki çocukların sahip oldukları kelime bilgisini ölçmektedir. Performans testidir ve bireysel olarak uygulanır. Test her biri dört resimden oluşan 100 karttan ve ayrıca kayıt formundan oluşmaktadır. Çocuklardan, onlara gösterilen kartın üstündeki dört resimden sorulanı göstermesi istenir (Öner, 1997). Özel hazırlık gerektirmeyen bir test olup, testi uygulayacak kişinin testteki her kelimenin söylenişini bilmesi, testin verilişine ait tüm bilgileri öğrenmesi gerekmektedir. Peabody Resim Kelime Testinin puanlamasında ham puan, tüm doğru yanıtların toplanmasıyla hesaplanır.

Tifaldi Dil Gelişim Testi. Ülkemiz için geniş yaş aralığına yönelik, alıcı dilin kelime bilgisini değerlendirebilecek özgün, güvenilir ve geçerli bir test ortaya koymak amacıyla Kazak-Berument ve Güven (2013) tarafından geliştirilmiştir. Tifaldi Türkçe dilini esas alan, uyarlama olmayan, özgün bir dil testidir. Testin içeriğinde Alıcı Dil Kelime Alt Testi için soyut ve somut şekilde ve farklı zorluklarda 242 kelime bulunmaktadır. Pilot verilerin elde edilmesi için Ankara ilinden 648 çocuğa, norm veriler için ise Türkiye bazında 61 ilden 3755 çocuğa ulaşılmıştır. Sonrasında pilot çalışmadan elde edilen verilere dayalı olarak madde güçlüğü, madde ayırt ediciliği ve çeldirici uygunluğu analizleri yapılmış, işlerliği aynı/düşük maddeler atılarak, sonuç olarak test 157 kelimeye indirilmiştir. Norm bilgilerine üç parametreli IRT madde analizleri BILOG-MG programıyla yapılmış ve sonuç olarak Alıcı Dil Kelime Alt Testi 2-12 yaş aralığında 104 madde ile kullanıma hazır hale getirilmiştir. Güvenilirlik çalışması sonunda test-tekrar test ve iç tutarlılık katsayılarının tüm örneklem ve her yaş grubu için hesaplandığında yüksek oldukları bulunmuştur. Alıcı Dil Kelime Alt Testi geçerlik çalışması amacıyla testin WISC-R genel, WISC-R sözel ve WISC-R performans, Ankara Gelişim Tarama Envanteri (AGTE) t puanı ve AGTE dil bilişsel gelişim alt puanları ile anlamlı şekilde ilişkili olduğu görülmüştür (Kazak-Berument ve Güven, 2013).

Akran Sosyometri Ölçeği. Sosyometrik teknikler, bir grup içerisinde bulunan bireyler arasındaki toplumsal ilişkileri inceleyip ortaya çıkarmaya yarayan tekniklerdir. Sosyometrik tekniklerin, okullardaki sınıf-içi toplumsal yapıyı incelemede ve özellikle çocuklar arasındaki arkadaşlık ilişkilerini belirlemede önemli bir yeri vardır (MEB, 2016). Benzer şekilde üstün yetenekli çocukların hem tespit edilmesinde hem de içinde bulundukları sosyal grup içindeki ilişkilerinin belirlenmesinde sosyometri yönteminden yararlanılabilir (Sutherland, 2012). Bu çalışmada da özellikle Rüzgâr'ın sosyo-duygusal gelişim ve arkadaşlık ilişkileri konusundaki durumunun netlik kazanması konusunda ihtiyaç oluştuğundan okul öncesi öğretmeni vasıtasılyla sınıfta bulunan çocuklarla sosyometri uygulaması yapılmıştır. Çocukların yaşlarının küçük olması, okuma yazma bilmiyor olmaları ve sürecin yetişkin denetiminde etik ve pedagojik kurallara uygun sürdürülmesi amaciyla Rüzgâr'ın öğretmeni Aysel hanıma öncelikle bu teknik tanıtılmış, uygularken dikkat edilmesi gereken kurallar- örneğin soruların çocuklara soruluş biçimi, cevapların gizliliğinin önemi vb. detaylarıyla açıklanmış uygulama sırasında da ilk uygulamalar araştırmacı danışmanlığında gerçekleştirilmiştir. Daha sonrasında öğretmenden farklı günlerde serbest oyun zamanlarında sınıfındaki öğrencilerle tek tek sohbetler ederek ve bu yaş grubuna uygun sorular sorarak (Örneğin; Eğer sınıfımızdan biriyle sohbet etmek isteseydin, bu kim olurdu? Sınıfta puzzle yapmak için birinden yardım isteseydin bu kim olurdu? Sayı sayarken yardıma ihtiyacın olsaydı, kimden yardım isterdin? vb.) sınıf içindeki sosyal iklim konusunda bilgi edinmek amaçlanmıştır. 
Stanford-Binet Zekâ Testi. Asıl ismi, "Stanford-Binet Intelligence Scale"dir. A. Binet, T. Simon, L. M. Terman ve M.A. Merrill tarafindan 1960 yılında geliştirilen testin Türkçe'ye uyarlanması Uğurel-Şemin (1987) tarafından yapılmıştır. Test, 2-18 yaş aralığındaki çocuk ve ergenlere uygulanabilmektedir ve çocukların bilişsel gelişimlerini değerlendirmeyi amaçlamaktadır. Ölçek sözel ve performans bölümlerinden oluşmaktadır ve her iki bölümün kendine özgü alt ölçekleri bulunmaktadır. Küçük yaşlarda performans maddelerinin sayısı daha fazlayken, artan yaşla birlikte sözel maddelerin sayısı da artmaktadır. İki ile beş yaş arasında alt ölçekler 6'şar ay arayla, 5-14 yaş arası alt ölçekler ise birer y1llık aralarla düzenlenmiştir. (Uğurel-Şemin, 1987).

\section{Veri Toplama ve Analizi}

Öncelikle Rüzgâr'ın annesi ve babasıyla bir ön görüşme gerçekleştirilmiştir. İlk görüşme ve sonraki görüşmeler araştırmacının ofisinde gerçekleştirilmiş, Rüzgâr'a uygulanan testler ise kendini rahat ve güvende hissetmesi açısından okul ortamında gerçekleştirilmiş̧ir. Aileyle yapılan görüşmeler ve Rüzgâr'a uygulanan testler 3 aylık bir zaman zarfına yayılacak şekilde tamamlanmıştır. Rüzgâr'ın test performansının etkilenmemesi için aynı gün içinde iki farklı test uygulanmamış, farklı günlere yayılmıştır. Rüzgâr'a uygulanan test ve ölçekler araştırmacı tarafından uygulanmış, zekâ testi uygulaması için test uygulama sertifikası olan ve üstün yetenekli çocuklarla çalışan psikoloji alanındaki akademisyen uzmandan destek alınmıştır.

\section{Bulgular}

Nitel bir örnek olay çalışması şeklinde kurgulanan bu araştırmanın bulgular kısmında 5 yaş 3 aylık olan üstün potansiyelli bir çocukta görülen eş zamanlı olmayan gelişim tablosu ortaya konmaya çalışılmıştır. Bu süreçte gerçekleştirilen aile ve ögretmen görüşmeleri, gözlemler ve uygulanan test ve ölçeklere ilişkin bilgiler bahsedilen sırayla bulgular kısmında paylaşılacaktır.

\section{Aile Görüşmelerinden Elde Edilen Bulgular}

Annesi, Rüzgâr'ın düşünce süreçlerinin diğer çocuklardan farklı olduğunu belirtmiștir. Rüzgâr'ın bir cevap ile hiçbir zaman yetinmediğini, hep daha fazla bilmek istediğini aktarmıştır. Annesi sıklıkla kendisini Rüzgâr'ın iyi eğitilmesi ve hak ettiği eğitime ulaşması için yetersiz hissettiğini, onun sorularına yeterli açıklamaları verebilecek kadar zeki olmadığını düşündüğünü belirtmiştir. Ailelerinde daha önce kimsenin üstün yetenekli olarak tanılanmadı̆̆ını, lise eğitiminden fazlasını da tamamlamadığını aktarmıştır.

\section{Okul Öncesi Öğretmeni ile Yapılan Görüşmelerden Elde Edilen Bulgular}

Rüzgâr, değerlendirmeler yapıllyor iken bir yıl süredir anaokuluna devam etmekteydi. Öğretmeni onun parlak bir çocuk olduğunu fakat sınıfta diğer çocuklarla geçinemeyen, onlara patronluk taslayan bir tavır sergilediğini söylemiştir. Rüzgâr'ın okul öncesi öğretmeni onun okulda davranış problemleri olduğunu aktarmış, diğer çocukların oyunlarına karıştığını, onlara daha karmaşı oyunlar sunmaya çalıştığını fakat reddedilince de öfkesini kontrol edemediğini belirtmiştir. Bu tarz sosyal durumlarda dışlanmışlık yaşadığında önce çok şiddetli mutsuzluk ve öfke gösterdiğini, daha sonra kendi içine kapanarak çok fazla gündüz rüyası benzeri durumlar yaşadığından bahsetmiştir. Rüzgâr'ın kendi yaşıtlarından çok okuldaki diğer öğretmenler, okul idarecileri, okul çalışanları gibi yaş ve deneyim olarak daha büyük insanlarla çok rahat iletişim kurduğunu fakat yaşıtlarına geldiğinde aynı sosyal iletişimi yakalayamadığını paylaşmıştır. Yaşıtlarıyla birlikte olduğu ortamlarda çok da iyi olmadığı sosyal ilişkileri çözmek, oyun kurallarına uymak, söz kesmek ve bilmediği konularda dahi bildiğini söyleyip bunda 1srarcı olmak gibi özellikleri olduğu belirtilmiştir.

\section{Çocuk Gözleminden Elde Edilen Bulgular}

Rüzgâr ile genel olarak ilgileri, merakları, sosyal iletişimi vb. konularda bilgi edinmek için araştırmacı tarafından kısa süreli görüş̧meler yapılmıştır. Bu görüşmelerde başlangıçta çekingen olduğu görülse de ilgilendiği konular üzerine sorulan soruları cevaplama ve bildiklerini aktarma konusunda istekli ve hevesli olduğu, yetişkinle kurduğu iletişimde oldukça akıcı olduğu görülmüsşür. Bu ilk görüşmelerin devamında kendisine uygulanan testler sırasında son derece uyumlu davranmıştır. Test uygulamaları sırasında tutarlı bir şekilde öz düzenleme göstererek, 
alışılmışın ötesinde bir dikkat süresi sergilemiştir. Uzun bir dikkat süresi, karşısındakini memnun etmek için hevesli bir duygu durumu göstermiştir. Test başlangıçlarında, sohbetler sırasında ve uygulamalar bittikten sonra ayrılma aşamalarında ona sorulan soruları cevaplamak ve verilen işleri tamamlamak için tutarlı bir çaba sergilediği gözlemlenmiştir. Birebir etkileşimde oldukça rahat olduğu gözlemlenen Rüzgâr'in sosyal ortamlarda arkadaşlarıyla yaptıkları veya en iyi arkadaşının kim olduğu gibi soruları cevaplarken aynı istekliliği sergilemediği ve dikkatini başka konulara kaydırdı̆̆ gözlemlenmiştir.

\section{Testler, Ölçekler ve Gelişim Envanterlerinden Elde Edilen Bulgular}

Üstün Yetenek Derecelendirme Ölçeği. Rüzgâr'ın ailesi ve öğretmeni tarafindan doldurulan ölçekte hem öğretmen hem de ailesinin, maddelerin \%70 den fazlasını "Çoğunlukla" şeklinde işaretlediği görülmüştür. Bu da Rüzgâr'ın üstün yetenekli çocuklarda var olan ve gözlemlenebilen pek çok davranışsal özelliği sıklıkla sergilediğini ortaya koymuştur. Rüzgârın özellikle ifade edici dil ve düşünme süreçleri başlıkları altındaki tüm maddelerin "Çoğunlukla" şeklinde işaretlendiği görülmüştür. Bu aşamadan sonra Rüzgâr'la ilgili diğer test ve ölçek uygulama aşamalarına geçilebilmiştir.

Tifaldi dil gelişimi testi. Beş yaş üç aylık Rüzgâr'ın Tifaldi alıcı dil alt test standart puanı 128; yaş eşdeğeri 8 yaş 6 ay olarak saptanmıştır. Rüzgâr'ın Tifaldi ifade edici dil alt test standart puan karşılığı ise norm değerlerinin çok fazla üzerine çıkmış olduğu için tespit edilememiştir; yaş eşdeğeri ise 12 yaş ve üstü olarak saptanmıştır.

Peabody resim-kelime testi. Rüzgâr, Peabody resim kelime testinde sunulan 100 kartın üzerinde kendisine sorulan tüm kelimelerin hepsini de bilmiş ve testi sonuna kadar büyük bir dikkat ve uyumlu davranış ile tamamlamıştır. Sonuç olarak, 5 yaş 3 aylık Rüzgâr Peabody Resim Kelime Testi sonuçlarına göre alıcı dilde 12 yaş özelliklerini sergilediği gözlemlenmiştir. Hatta test bittikten sonra araştırmaciya daha da devam etmesini istediğini, çok keyif aldığını paylaşmıştır. Test uygulamasından çıkarken, kendi kurguladığı bir kelime oyunu olduğunu, bir dahaki sefere bu oyunu getirip araştırmacıya bu sefer onun sorular soracağını söylemiştir.

Denver II gelişim tarama testi. Rüzgâr'a, annesi eşliğinde araştırmacı tarafından Denver II Gelişim Tarama Testi uygulanmıştır. Rüzgâr test sırasında sırasıyla Kişisel-Sosyal, İnce Motor, Dil ve Kaba Motor testlerinin tamamını başarıyla bitirmiştir. Beş yaş 3 aylık olan Rüzgâr, bu test sonucunda yaşından daha üst seviyede performans göstererek kişisel sosyal ve ince motor başlığı altındaki birer madde haricinde tüm maddeleri tamamlamış ve 6 yaş seviyesinde son bulan testin son sorusuna kadar başarıyla ilerlemiştir. Tüm test boyunca devam eden test davranışları gözlemlendiğinde, başlangıçta biraz kaygı göstermiş olsa da test süresince ortama ve uygulayıcıya alışarak testin kalan zamanında uyumlu davranışlar gösterdiği gözlemlenmiştir.

Akran sosyometri ölçeği. Rüzgâr'ın öğretmeni Aysel hanıma verilen danışmanlık sonucu sınıfta bulunan 13 öğrenci ile öncelikle araştırmacı mentörlüğünde, sonrasında ise öğretmen kendisi sınıfında bulunan çocuklarla birebir görüşmeler yapıp daha önce örnekleri verilmiş olan tarzda 8 soru yöneltmiştir. Bu sorulardan toplanan cevaplara göre çocuklar genel olarak sınıf içi iletişim örüntüleri konusunda bilgiler vermişler, bu bilgiler içerisinden Rüzgâr'ın sosyal ilişkileri hakkında da bilgiler edinilmiştir. Buna göre çocuklar sosyal bir problem çözmek veya sosyal ilişki kurmak, sohbet etmek gibi durumlarda başvuracakları arkadaşları olarak Rüzgâr'ın adını vermemekle birlikte, çözmeye çalıştıkları bir soru, ezberleyemedikleri, hatırlayamadıkları bir bilgi vb. olduğunda Rüzgâr'ın bu tarz görevler için uygun bir aday olabileceğini belirtmişlerdir.

Stanford-Binet zekâ testi. Stanford-Binet Zekâ Testinin uygulaması sonucunda Rüzgâr'ın aşağıda detaylı şekilde aktarılmış olan alt testlerin tümünde de takvim yaşından 2 yaş ila 3 yaş üstte çıktığ görülmüştür. İlk olarak Sözel Akıl Yürütme bölümüne ilişkin, "Sözcük bilgisinin, dil gelişiminin ve sözel akıc1lık" yeteneklerinin yaşıtlarından 2 yaş ileride olduğu saptanmıştır. Muhakeme, akıl yürütme, pratik bilgi, soyut düşünme, bilgilerini organize etme becerisinin, neden sonuç ilişkisi kurma gücünün ve eleştiri yeteneğinin, sözel soyut düşünme kapasitesinin, bilgileri depolama ve çağrıldığında yeniden gruplama ile bilgileri kullanma becerisinin yaşıtlarından 3 yaş üzerinde bir gelişim gösterdiği anlaşılmıştır. Soyut/Görsel Akıl Yürütme Bölümü 
kısmında, dikkat, çevresel uyarıcıları algılama kapasitesi ile çevreye ve ayrıntılara duyulan ilginin, ayrıca Niceliksel Yargılama Bölümünde de, dikkatini bir probleme yönlendirebilmede, algı hızında, deneme-yanılma yöntemini kullanma becerisinde ve sayısal kavramlar üzerinde akıl yürütebilme becerisinde yaşıtlarının 2 yaş üzerinde gelişim gösterdiği anlaşılmıştır. Kısa Süreli Bellek Bölümünde ise sözel bellek kullanımı, dikkat yoğunlaştırma, görme belleği gücü, çağrışımsal düşünebilme, kategorilere koyma ve genelleme becerileri ile yeni bir görevi öğrenebilme kapasitesinin yaşıtlarından 2 yaş üstte olduğu görülmüş, görsel uyaranları anımsama ve yoğunlaşma ile görsel alg1-motor koordinasyon yeteneklerinin yaş düzeyine göre bir yaş üzerinde olduğu kaydedilmiştir. Sonuç olarak Rüzgâr'a uygulanan Stanford-Binet Zekâ Testi sonucunda kendisinin "Üstün Düzeyde Zekâ" zihinsel performansına sahip olduğu belirlenmiştir.

\section{Sonuç ve Tartışma}

Üstün yetenekli çocukların çoğunluğunda görülen hatta bazı kaynaklara göre üstün yetenekli olma durumunu tanımlayan en önemli kavramlardan olan "üstün yeteneklilerdeki eş zamanlı olmayan gelişim” konusu bu alanda çalışan uzmanlar, öğretmenler ve ayrıca aileler tarafından ivedilikle fark edilmesi ve üzerinde çalışmalar yapılması gereken konulardan birisidir. Üstün yeteneklilerle ilgili en çok bilinen önyargılardan olan "Üstün yetenekli kişi her alanda üstündür" düşüncesiyle hareket etmenin, bu grup çocuğa akademik ve sosyal-duygusal anlamda pek çok sorun yaşatacağı ortadadır. Bu sorunları önceden görerek üstün yeteneklilerdeki eş zamanlı olmayan gelişim durumu, bu çalışmada 5 yaş 3 aylık üstün potansiyelli bir erkek çocuk olan Rüzgâr örneği üzerinden gidilerek analiz edilmeye çalışılmıştır. Bu analiz sırasında hem Rüzgâr'la hem annesi ve babasıyla hem de okul öncesi öğretmeniyle görüşmeler yapılmış, Rüzgâr'a ilişkin anekdota dayalı bilgiler elde edilmiş, aile ve öğretmenine kontrol listeleri verilmiştir. Bunlardan elde edilen bilgiler ışığında bir sonraki aşamada daha net bilgiler elde etmek adına Rüzgâr'ın yaşı ve ayrıca pedagojik yaklaşım gereği, fiziksel ve psikolojik olarak rahat olduğu zamanlarda çeşitli testler (Tifaldi Dil Gelişim Testi, Peabody Resim-Kelime Testi, Denver Gelişim Tarama Testi, Stanford-Binet Zekâ Testi) uygulanmış, aynı zamanda okul öncesi öğretmenine destek olunarak uzun vadeye yayılmış şekilde sınıf içinde sosyometri uygulaması gerçekleştirilmiş ve ilgili bilgiler toplanmıştır. Tüm bu değerlendirmeler sonucunda, Rüzgâr'ın dil gelişiminde ve zihinsel gelişimde, becerilerinin çok üstün olduğu, bununla birlikte bu alanlardaki hızlı gelişimi sonucu ortaya çıkan durumlar nedeniyle akranlarıyla sosyal ve duygusal anlamda sorunlar yaşadığı net bir şekilde ortaya konmuştur. Gerçekleştirilen bu değerlendirme süreci sonunda Rüzgâr'ın üstün yetenekli çocuklara özgü eş zamanlı olmayan gelişimi özellikle sosyo-duygusal gelişim alanında gösterdiği netlik kazanmıştır.

Daha önce de aktarıldığı gibi üstün yetenekli çocuklardaki eş zamanlı olmayan gelişim, onların hayatlarının önemli bir parçasıdır ve neredeyse üstün yetenekli olmayı tanımlayacak kadar güçlü bir kanıttır (Adler, 2006; Kokot, 1999; Morelock, 1996; NAGC, 2016; Strip ve Hirsch, 2000; Terassier, 1985). Çoğu kaynak, üstün yetenekli çocukların zihinsel gelişimleri açısından akranlarından önde olmalarına karşın sosyal-duygusal ve/veya fiziksel gelişimde bu durumu gösteremeyebilecekleri durumundan bahsetmiştir (Kearney, 1992; Lovecky, 1998; Morelock ve Morrison, 1999; Porter, 1999; Silverman, 1994, 1997, 2002). Rüzgâr örneğinde karşımıza çıkan tablodaki eş zamanlı olmayan gelişim de sosyal-duygusal gelişim alanında karşımıza çıkmıştır. Burada tartışılması gereken önemli bir nokta aslında Rüzgâr'ın sosyal ortamlarda gösterdiği kızgınlık, sosyal uyum sorunu veya arkadaşlarına patronluk taslama gibi konuların, onun sosyal-duygusal anlamdaki yetersizliği odaklı olmadığıdır. Bu tarz hayal kırıklıklarının sürekli tekrarlanması durumu ise bu davranışların da zamanla yerleşmesine sebep olacağı düşünülebilir. Tahmin edileceği gibi bir çocuk üstün yetenekli de olsa sonuç olarak çocuktur ve bir çocuğun sahip olmak isteyeceği arkadaşlar, sosyal etkileşimler ve oyunlara ihtiyaç duymaktadır. Gerçekte olan ile hayal ettikleri arasındaki mesafe arttıkça bu durum üstün yetenekli çocuklarda ilerleyen zamanlarda kalıcı duygusal sıkıntılara da yol açabilmektedir (Saranlı ve Metin, 2011). Dolayısıyla, sosyalduygusal anlamda zorluklar yaşadığı görülen üstün yetenekli çocuklara destek olma aşamasında hem kendilerini hem de çevrelerindeki dünyayı nasıl algıladıkları konusunda gerçekçi ve olumlu bir algıya sahip olmaları sağlanmalıdır. Bu destek ailesi ve öğretmenlerinden alındıktan sonra onlara uygun Bireyselleştirilmiş Eğitim 
Programları hazırlama aşamasına geçilerek daha sağlam adımlarla ihtiyaçları olan ortamlar yaratılabilecektir (Adler, 2006; Silverman, 2002; Terassier, 1985).

\section{Öneriler}

Örnek olay çalışması boyunca gerçekleştirilen analizlerin sonuçları, Rüzgâr'ın durumunun net bir şekilde anlaşılabilmesini ve ona uygun eğitim ve sosyal ortamların yaratılabilmesini sağlamada ipuçları sağlamaktadır. Bu ipuçlarından faydalanarak hem Rüzgâr hem de eş zamanlı olmayan gelişim gösteren üstün yetenekli çocuklar için geliştirilebilecek erken müdahale yollarına ilişkin çeşitli öneriler geliştirilmiştir. Rüzgâr'a ilişkin yapılan değerlendirmeler sonucunda ortaya çıkan ve bu çalışmanın sonucunda öneri niteliğinde sunulabilecek en önemli ilk konu, zaman geçirilmeden eş zamanlı olmayan gelişim gösteren bu tarz üstün yetenekli çocuklara özgü 'Bireyselleştirilmiş Eğitim Programı' (BEP) hazırlanmasının gerekliliğidir. Aynı, özel gereksinimli çocuklar gibi üstün yetenekli çocukların da BEP programlarından yararlanmasının sağlanması, bu şekilde erken müdahale sistemlerinin çocukla ilgili bilgiler netleştikten sonra zaman geçirilmeden uygulamaya konulması açısından çok önemlidir. Rüzgâr'a özgü hazırlanacak bir BEP planında katılımcılar elbette ki, ailesi, öğretmeni ve alan uzmanları olmalı, bu ekip tarafından onun özellikleri dikkate alınarak hazırlanmalıdır. Rüzgâr'ın ailesine, onun için hazırlanan BEP'na destek olmalarının ne kadar önemli olduğu açıkça anlatılmalıdır. Daha sonrasında gerçekleştirilebilecek bir başka öneri, ailesine ve öğretmenine üstün yetenekli çocukların özellikleri, ihtiyaçları ve özel durumlarına yönelik olarak birebir eğitim verilmesi olabilir. Bu yolla yani aile eğitimi ve öğretmen eğitimi yoluyla ikinci ve çok önemli bir erken müdahale adımı daha atılmış olacaktır. Rüzgâr'ın ailesine evde, öğretmenine de okulda Rüzgâr'a davranış biçimleri, sorunları nasıl çözebilecekleri konusunda destek verilmelidir. Hem aile hem de çevresindekilere, BEP ekibini oluşturan diğer kişiler tarafından tutarlı şekilde ara görüşmeler yapılarak danışmanlık verilmeye devam edilmesi önerilebilir.

Bunlar dışında Rüzgâr'ın kendi akranlarıyla ve onunla ilgilenen yetişkinlerle arasındaki sosyal ilişkilerin kalitesini artırmak için çeşitli erken müdahale önlemleri alınabilir (ev, sınıf, okul, toplum vb.). Örneğin, okul öncesi dönemde bulunan üstün yetenekli bir çocuk olan Rüzgâr için yapılabilecek sosyal müdahalelerin başında kişiler arasındaki uygun etkileşimlerin geliştirilmesi ve uygun olmayanların tespit edilerek değiştirilmesi gelebilir. Bunun için öncelikle, Rüzgâr'ın hangi konularda ve hangi kişilerle sosyal iletişim sıkıntıları yaşadığı çeşitli gözlemler ve görüşmeler sayesinde tespit edilebilir. Bu tespit sırasında daha önceki süreçte elde edilmiş bilgilerden de mutlaka yararlanılmalıdır. Örneğin, Rüzgâr'a ilişkin elimizdeki bilgiler arasında, genellikle çok da iyi olmadığı sosyal ilişkileri çözmek, oyun kurallarına uymak, söz kesmek ve bilmediği konularda dahi bildiğini söyleyip bunda ısrarcı olmak gibi özelliklerinin olduğu görülmüştü. $\mathrm{Bu}$ gözlemlerin netlik kazanması, bu davranışları tetikleyenlerin neler olduğunun ve sıklıklarının nasıl olduğunun anlaşılması, Rüzgâr'a verilecek desteğin doğru şekilde biçimlendirilmesinde önem kazanacaktır. Rüzgâr'ın hayatında oldukça önemli bir yere sahip olan öğretmeninin de yapabileceği pek çok destek bulunmaktadır. Örneğin öğretmeni tarafından sosyal beceri içerikli ve çeşitli sosyal ilişki stratejilerini içeren öyküler, hikâyeler, küçük drama çalışmaları, öğretmeni tarafından günlük tecrübelere dâhil edilebilir. Yine öğretmeni tarafından, hem sınıftaki tüm öğrenciler arasında hem de okuldaki yetişkinler arasında fikirlerin ifade edilmesi ve duyguların dile getirilmesi için çeşitli ortamlar yaratılarak sadece Rüzgâr'ın değil, diğerlerinin de sosyal duygusal gelişimlerinin desteklenmesi sağlanabilir.

Bir başka öneri, Rüzgâr'ın duygularının ve kişilik özelliklerinin hem ailesi hem öğretmeni tarafından farkına varılması için daha çok çaba harcanması olabilir. Bunun için de aile ve öğretmen eğitimleri sırasında Rüzgâr için yapılan değerlendirmelerin sonuçları ekipte bulunan diğer yetişkinlerle açık bir şekilde paylaşılmalıdır. Bunlar dışında ailesinden, okul müfredatını ve öğrenmeyi destekleyici yardımlar da istenebilir. Bu sayede ailenin kendisini Rüzgâr'ın eğitimiyle ve onun desteklenmesiyle ilgili yetersiz hissetmesi durumu da azaltılmış olacaktır. Çünkü bu süreçte Rüzgâr'ın her zaman yanında olacak olan kişiler olan ailesinin kendilerini bu tarz bir çocuğu yetiştirme konusunda yeterli görebilmeleri oldukça önemlidir. Aile de hem kendilerinin hem de sınıflarındaki diğer ailelerin aile katılımı için yapabileceklerini görmeyi sağlayan bir aile listesi hazırlayabilirler. Örneğin, listeye ismini yazdıran aileler çocuklara alan gezilerinde, aile eğitimleri ve toplantıları düzenlenmesinde, sınıf etkinliklerine yardım etmede ve ilginç eğitsel materyaller bulmada yardımcı olabilirler. Böylece hem 
Rüzgâr'ın hem de sınıftaki diğer çocukların aileleri sürece dâhil edilmiş ve tüm sınıf için faydalı olabilecek bir zenginleştirme yöntemi hayata geçirilmiş olacaktır.

Zenginleştirme yönteminin sınıfta kullanımı, hem sınıftaki diğer çocuklar hem de Rüzgâr için yeni öğrenme deneyimlerini de beraberinde getirecektir. Bunun için hem Rüzgâr'ın hem de diğer çocukların hayal gücünü ve yaratıcılığını destekleyecek daha fazla materyal ve malzeme çeşidi sınıfa getirilebilir, böylece eğitim ortamının hem Rüzgâr hem de diğer çocuklar için daha da zenginleştirilmesi sağlanabilecektir. Sınıftaki tüm çocukların eğitimlerini ve gelişimlerini olumlu anlamda etkileyecek zenginleştirme gibi yöntemlerin kullanımı sayesinde diğer çocuklarda ve ailelerinde oluşabilecek Rüzgâr’a özel muamele yapıldığı önyargısının da önüne geçilmiş olunacaktır. Bunlar dışında Rüzgâr'ın okulunda yine hem Rüzgâr hem de diğer çocuklar için önemli bir öğrenme kazanımı olacak olan işbirlikli öğrenmeyi destekleyecek küçük grup aktiviteleri daha çok düzenlenmeye başlanabilir. Bu sayede hem Rüzgâr'ın başka çocukların bakış açılarını görüp daha güvenli bir ortamda sosyal becerilerini geliştirebilmek için ortamı olmuş, hem de diğer çocukların da grup halinde işbirlikli şekilde çalışmayı öğrenme konusunda deneyimi artmış olacaktır.

Bir başka öneri de hem evde hem de okul ortamında zihinsel olarak Rüzgârı uyarabilecek yetişkinlerin çocuğun hayatına dâhil edilmesidir. Bu sayede hem bilgi açısından daha zengin bir ortam oluşturulmuş, hem de daha fazla sosyal ortam ve ilişki çeşidiyle tecrübe kazanılmış olacaktır. Rüzgâr'a ailesi ve öğretmeni tarafından her gün karşılaşılabilecek sosyal durumların konuşulmasını sağlayacak hikâyeler okunabilir, bunlar birlikte karşılıklı şekilde Rüzgârla tartışılabilir. Son olarak, hem yaşıtlarıyla, hem de kontrollü ortamlarda daha büyük çocuklarla daha fazla sosyal etkileşime girebileceği çeşitli sosyal firsatlar ve etkileşim modelleri sağlanması önerilebilir.

Eş zamanlı olmayan gelişim kavramı, üstün yetenekli çocukların eğitimleri ve gelişimleriyle ilgilenen kişiler tarafindan bilinmesi gereken en önemli kavramlardan birisidir. Bu durumu tespit etmeye, bu durumu yaşayan çocuklar için BEP geliştirmeye ve alınması gereken önlemlere hâkim olan yetişkinlerin, üstün yetenekli çocukların hayatında çok büyük farklar yaratacağı ortadadır. Bu çalışmada 5 yaş 3 aylık Rüzgâr'ın eş zamanlı olmayan gelişim örüntüsünü ortaya koyma ve sonrasında yapılabilecekler konusunda çeşitli öneriler getirme vasıtasıyla bu kavramın üstün yetenekli çocuklar açısından ne kadar önemli olduğu ortaya konulmaya çalışılmıştır. Örnek olay çalışması yöntemiyle gerçekleştirilen bu çalışmada doğal olarak tek bir örnek üzerinden çoğu üstün yetenekli çocuğun yaşadığı bilinen eş zamanlı olmayan gelişim örüntüsü anlaşılmaya çalışılmıştır. Bununla birlikte bu örüntünün farklı üstün yetenekli çocuklarda farklı şekillerde görülebileceği de hiçbir zaman akıllardan çıkarılmamalıdır. Üstün yetenekli çocuklarda görülen eş zamanlı olmayan gelişim kavramının, bu konuyla ilgilenen araştırmacılar tarafından bundan sonraki çalışmalarda çeşitli şekillerde ele alınması önerilmektedir. Örneğin, eş zamanlı olmayan gelişimi erken fark etme ve erken müdahale etmede kullanılabilecek çeşitli tarama yöntemleri veya küçük yaştaki üstün yetenekli çocukların gelişim alanlarındaki farklılıklara yönelik zenginleştirilmiş etkinlikler geliştirme gibi konular bu alanda ihtiyaç duyulan ve ileride üzerinde araştırmalar yapılabilecek önemli konulardandır. Bunlar dışında çocuklarındaki eş zamanlı olmayan gelişimle başa çıkma konusunda ailelere verilecek eğitimlerin geliştirilmesi de halen ele alınmamış konulardan bir başkasıdır. Öğretmenlerin öğrencilerindeki farklı gelişimleri doğru yorumlamaları konusunda öğretmenlere rehberlik edecek programlar geliştirilmesi ve etkilerinin araştırılması da bu alanda ihtiyaç duyulan bir başka önemli araştırma konusudur.

Bu çalışmanın bazı sınırlılıklarından bahsedilmesi gerekli görülmüştür. Çalışmanın uygulama süresi test, ölçek ve gözlemlerin yapıldığı süre ile sınırlıdır. Bunun dışında eş zamanlı olmayan gelişimin farklı üstün yetenekli çocuklarda aynı bu örnek olaydaki gibi ortaya çıkmayabileceği, dolayısıyla örnek olay çalışmasının sınırlılıkları da göz önünde tutulmalıdır. Uygulama araçlarından derecelendirme ölçeği kapsam geçerliği sonrasında kullanılmış olması da bir başka sınırlılıktır.

Eş zamanlı olmayan gelişim üstün yetenekli çocuklarda eğitimciler, aileler ve çocukla ilgilenen uzmanlar tarafından özellikle göz önünde bulundurulması gereken çok önemli bir konudur. Üstün yetenekli çocukları her 
alanda üstün olarak nitelendirerek, onları mükemmel çocuk kalıbına sokmaya çalışmak, onlara yarardan çok zarar getirecek ve var olan potansiyellerini kullanmalarını engelleyecektir. Üstün yetenekli çocukların her türlü üstün becerilerinin dışında aslında temelde çocuk oldukları unutulmamalıdır. Herkesin sahip olması gereken hata yapma hakkı, bazı şeyleri de becerememe hakkı, her konuda üstün olmama hakkı gibi aslında onları rahatlatan, sonrasında da onları daha rahat keşfetmeye ve öğrenmeye yönlendiren hakları sonuna kadar savunulmalıdır. Üretken ve çevresine faydalı üstün yetenekliler kadar, mutlu, hayatla barışık ve kendini olgunlukla kabul etmiş üstün yetenekli çocuklar yetiştirebilmek de önemli olmalıdır. 
Kaynaklar

Adler, D. A. (2006). The effects of participating in support groups focusing on parenting gifted children (Doctoral dissertation). Retrieved from https://etd.ohiolink.edu/pg_10?0:NO:10:P10_ACCESSION_NUM:kent1161881173

Ataman, A. (2003). Özel eğitim/sorunlar, yaklaşımlar, öneriler: Üstün yetenekli/zekâlı çocuk ile yaşamak. Bilim ve Aklın Aydınlı̆̆ında Ĕ̈itim Dergisi, 4(39), 17-20.

Cresswell, J. W. (2007). Qualitative inquiry and research design (2nd ed.). Thousand Oaks, CA; Sage.

Dağlıoğlu, E. (2004). Okul öncesi çağdaki üstün yetenekli çocukların eğitimleri. I. Türkiye Üstün Yetenekli Çocuklar Kongresi'nde sunulan sözlü bildiri. ustunyeteneklicocuk.org/bildiri.docinternet adresinden elde edilmiştir.

Davis, G. A., Rimm, S. B., \& Siegle, D. (2011). Education of the gifted and talented (6th edition). New Jersey, NJ: Pearson Education.

Denver (2016). Denver gelişim testi. http://www.gcn.org.tr/tr/denver-ii-test adresinden elde edilmiştir.

Johnsen, S. K. (2005). Identifying gifted students: A step-by-step guide. In F. A. Karnes \& K. R. Stephens (Eds.), Practical strategies series in gifted education (pp. 6-20). Waxo, TX: Prufrock Press.

Karakuş, F. (2010). Üstün yetenekli çocukların anne babalarının karşılaştıkları güçlükler. Mersin Üniversitesi Ĕ̌itim Fakültesi Dergisi, 6(1), 127-144.

Kaya, F. (2015). Öğretmenlerin üstün zekâ kavramı ve üstün zekâlı öğrencilerin özel gereksinimleri. Eğitim ve Bilim, 40(177), 59-74.

Kazak-Berument, S., \& Güven, A. G. (2013). Türkçe ifade edici ve alıcı dil (TİFALDİ) testi: Alıcı dil kelime alt testi standardizasyon ve güvenilirlik-geçerlik çalışması. Türk Psikiyatri Dergisi, 24(3), 192-201.

Kearney, K. (1992). Life in the asynchronous family. Understanding Our Gifted, 4(6), 8-12.

Kokot, S. (1999). Help! Our child is gifted: Guidelines for parents. Lyttelton, South Africa: Radford House Publications.

Leana-Taşçılar, M. Z., Özyaprak, M., Güçyeter, Ş., Kanlı, E., \& Camc1-Erdoğan, S. (2014). Üstün zekâlı ve yetenekli çocuklarda mükemmeliyetçiliğin değerlendirilmesi. Hasan Âli Yücel Eğitim Fakültesi Dergisi, 11 (21), 31-45

Levent, F. (2014). Üstün yetenekli çocukları anlamak: Üstün yetenekli çocuklar sarmalında aile, eğitim sistemi ve toplum. Ankara: Nobel Yayın.

Lovecky, D. V. (1993). The quest for meaning: Counseling issues with gifted children and adolescents. In L. K. Silverman (Ed.), Counseling the gifted and talented (pp. 29-50). Denver, CO: Love Publication.

Lovecky, D. V. (1998). Spiritual sensitivity in gifted children. Roeper Review, 20(3), 178-183.

$\begin{array}{llll}\text { Milli } & \text { Eğitim } & \text { Bakanlı̆̆ } & \text { (2016). }\end{array}$ mebk12.meb.gov.tr/meb_iys_dosyalar/38/03/.../2012.../21024844_sosyometri.doc adresinden elde edilmiştir.

Merriam, S. B. (2009). Qualitative research: A guide to design and implementation (3rd ed.). San Francisco, CA: Jossey Bass.

Miles, M. B., \& Huberman, A. M. (1994). Qualitative data analysis: An expanded sourcebook (2nd ed.). Thousand Oaks, CA: Sage. 
Morelock, M. J. (1996). On the nature of giftedness and talent: Imposing order on chaos. Roeper Review, 19(1), 4-12.

Morelock. M. J., \& Morrison, K. (1999). Differentiating 'developmentally appropriate': The multidimensional curriculum model for young gifted children. Roeper Review, 21(3), 195-200.

National Association for Gifted Children. (2016). Asynchronous development. http://www.nagc.org/resourcespublications/resources/social- emotional-issues/asynchronous-development adresinden elde edilmiştir.

Öner, N. (1997). Türkiye'de kullanılan psikolojik testler: Bir başvuru kaynă̆ı. İstanbul: Boğaziçi Üniversitesi Matbaas1.

Özgüven, İ. E. (1998). Psikolojik testler. Ankara: Yeni Doğuş Basımevi.

Saranl1, A. G., \& Metin, N. (2012). Üstün yetenekli çocuklarda gözlenen sosyal-duygusal sorunlar. Ankara Üniversitesi Eğitim Bilimleri Fakültesi Dergisi, 45(1), 139-163.

Silverman, L. K. (1994). The moral sensitivity of gifted children and the evolution society. Roeper Review, 17(2), 110-116.

Silverman, L. K. (1997). The construct of asynchronous development. Peabody Journal of Education, 72(3-4), 36-58.

Silverman, L. K. (2002). Asynchronous development. In M. Neihart, S. M. Reis, N. M. Robinson \& S. Moon (Eds.), The social and emotional development of gifted children: What do we know? (pp. 31-37). Waco, TX: Prufrock Press.

Stake, R. E. (2005). Qualitative case studies. In N. K. Denzin \& Y. S. Lincoln (Eds.), The Sage handbook of qualitative research (pp. 443-466). Thousand Oaks, CA: Sage.

Strip, C.A., \& Hirsch, G. (2000). Helping gifted children soar: A practical guide for parents and teachers. Scottsdale, AZ: Great Potential Press.

Sutherland, M. (2008). Developing the gifted and talented young learner. London: Sage.

Sutherland, M. (2012). Gifted and talented in the early years: Practical activities for children aged 3 to 6 (2nd ed.). London: Sage.

Terrasier, J. C. (1985) Dyssynchrony: Uneven development. In J. Freeman (Ed.), The psychology of gifted children: Perspectives on development and education (pp. 265-274). Great Britain: John Wiley and Sons.

Tortop, H. S., \& Eker, C. (2014). Üstün yetenekliler eğitim programlarında öz-düzenlemeli öğrenme neden yer almalıdır? Üstün Yetenekliler Eğitimi Araştırmaları Dergisi, 2(1), 23-41.

Uğurel-Şemin, R. (1987). Stanford-Binet ölçeğinin İstanbul çocuklarına uygulanması. İstanbul: İstanbul Üniversitesi Fen Fakültesi Yayınları.

Webb, J. T., Gore, J. L., Amend, E. R., \& DeVries, A. (2007). A parent's guide to gifted children. Scottsdale, AZ: Great Potential Press.

Wolcott, H. F. (1992). Posturing in qualitative inquiry. In M. D. LeCompte, W. L. Millroy \& J. Preissle (Eds.), The handbook of qualitative research in education (pp. 3-52). Orlando, FL: Academic Press.

Yıldırım. F. (2012). Üstün yetenekli çocuklar ve ailelerinde duygusal ve davranışsal özellikler (Yayımlanmamış tıpta uzmanlık tezi). Dokuz Eylül Üniversitesi Tıp Fakültesi, İzmir.

Yin, R. K. (2008). Case study research: Design and methods (4th ed.). Thousand Oaks, CA: Sage. 


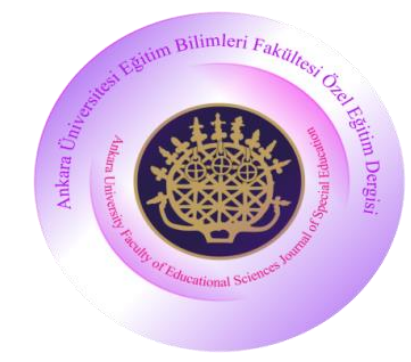

RESEARCH

\section{Ankara University Faculty of Educational Sciences Journal of Special Education}

\author{
Year: 2017, Volume: 18, No: 1, Page No:89-108
}

DOI: 10.21565/ozelegitimdergisi.300060

\title{
A Case Study on the Manifestation of Asynchronous Development in Gifted Children
}

\author{
Adile Gülşah Saranlı* \\ TED University
}

\begin{abstract}
Giftedness is defined as showing superior performance compared to peers in a specific developmental area. In this context, the commonly held preconception is that gifted children are superior in all areas. However, compared to their peers, they may be superior in certain areas, while being typical in others. Such differences in developmental speed in different areas is called "asynchronous development." This concept is considered to be quite important for groups with special needs and has been the focus of different studies. Despite being one of the defining characteristics of giftedness, asynchronous development is often overlooked, not studied in depth and does not receive sufficient attention, motivating the focus of this paper. In the study, asynchronous development patterns of a child with gifted potential at the age of 5 years and 3 months, to whom we will refer to as Ruzgar, are presented using a case analysis method, thereby concretizing the concepts behind, and the recognition of, typical asynchronous development patterns. It is hoped that this study will support the long-term social-emotional development of gifted children, helping parents and teachers address potential problems before they occur by understanding both academic and social behavioral patterns of gifted children. Possible ways of early intervention are also discussed in light of observations and conclusions from the case study, providing suggestions for experts as well as teachers and parents of gifted children.
\end{abstract}

Keywords: High potential, gifted, asynchronous development, early intervention, case study.

\section{$\underline{\text { Recommended Citation }}$}

Saranl1, A. G. (2017). A case study on the manifestation of asynchronous development in gifted children. Ankara University Faculty of Educational Sciences Journal of Special Education, 18(1), 89-108.

*Corresponding Author: Assist. Prof. Dr., TED University, Faculty of Education, Department of Elementary Education, Early Childhood Education, Ankara, E-mail: gsaranli@gmail.com 
The speed and intensity of development patterns exhibited by gifted children in different areas are often ahead of children with typical development. At first, this difference is a source of concern for both parents and educators. People interacting with gifted children observe their advanced skills in certain areas and assume that they will be similarly advanced in all areas of their development. In reality, however, gifted children may indeed seem more advanced than their peers in certain areas, but may also show normal and even delayed development in other areas. This situation is called Asynchronous Development. Incomplete awareness that gifted children are more likely to exhibit asynchronous development patterns, and a lack of accurate information on this concept, is an important risk factor for gifted children. One of the most effective early intervention methods to protect both academic and social-emotional development of gifted children would be to increase the knowledge and awareness of parents, teachers, and experts on this concept. In summary, this study seeks to use the case study method on a potentially gifted 5 years and 3 months-old child exhibiting asynchronous development to identify areas in which this asynchrony is observed, as well as the intensity and nature of associated differences, with the subsequent discussion of early intervention methods applicable in similar situations.

\section{Method}

In this study, the qualitative "Case Study" pattern, which allows in-depth description and analysis of a limited system is used. This was deemed to be the most suitable research pattern since this study focuses on the identification of a child with the gifted potential exhibiting asynchronous development through different observations, interviews, and scales. In this study, individuals who participated in interviews, observations, and scale implementations were the child, parents, and teachers. Data collection methods employed in this study were organized as observations of the child by the researcher, his parents, and the teacher; interviews with parents and teachers as well as the implementation of relevant scales. Tests and scales used for the study were the Giftedness Rating Scale, Denver II Developmental Screening Test, the Peabody Picture Vocabulary Test, the Tifaldi Language Development Test, and the Stanford-Binet Intelligence scale.

\section{Results}

Following the first interview with Rüzgar's parents, they were asked to fill out a Gifted Rating Scale, listing their views on typical characteristics of gifted children. Based both on this list and Ruzgar's developmental differences becoming more apparent, individual meetings with Ruzgar's parents were continued. Ruzgar's mother indicated that his thought processes were different from other children. He was never satisfied with a single answer, always wanted to know more. His mother often felt inadequate for Ruzgar, feeling that she was not sufficiently smart to provide adequate explanations for his questions. Nobody in their family was previously identified as gifted, and the highest level of education was high school.

Ruzgar was very cooperative during all the tests. He consistently showed self-regulation and an unusually long attention span, often trying to please people he interacted with. Both at the beginning of the tests, during the conversations and after activities, he consistently tried to answer questions and complete his assignments. However, even though Ruzgar was comfortable during one-to-one interactions, he was not as willing when asked questions related to activities he liked to do with his friends in social environments, or whom his best friends were, quickly diverting his attention to different topics.

His teacher observed that he was bright, but did not get along well with other children in his class, often bossing them around. He interfered with other children's games, tried to get them to play more complex games but could not control his temper when rejected. When faced with situations involving social exclusion, he first showed extreme unhappiness and anger, with subsequent withdrawal into himself, showing behaviors similar to daydreaming. The teacher indicated that Ruzgar had an easier time communicating with older people with more experience, such as other teachers, administrators, and employees, but had difficulty achieving the same frequency and quality of communication with his peers. 
The first test that was applied in Ruzgar's case was the Gifted Rating Scale, with most of its items selected by the parents. Ruzgar was hence found to exhibit many of the behavioral characteristics for giftedness. Subsequently, other tests and scales were applied. Ruzgar, who was 5 years and 3 months old, had a standard score of 128 in the Tifaldi receptive language subtest with an equivalent age of 8 years and 6 months. Ruzgar's results in the expressive Tifaldi subtest were outside the norm values and hence did not yield a standardized score, corresponding to an equivalent age of 12 or more. Ruzgar was able to identify all the words in the Peabody picture vocabulary test, completing the test with exceptional focus and positive attitude. He also completed all items except one under the sections for personal social and fine motor skills within the Denver II Developmental Screening test, which has a ceiling age of 6 . In conclusion, Ruzgar was found to have exceptional skills in language, memory, and reasoning, while showing delayed development in social-emotional areas. As a result of this evaluation, Ruzgar showed asynchronous development patterns characteristic of gifted children particularly in social-emotional developmental areas.

\section{Discussion and Conclusion}

“Asynchronous development in gifted children," observed in most gifted children and may, in some cases, be even used as a definition of giftedness; needs to be urgently recognized and focused on by parents, experts, and teachers. It is clear that acting on the preconception that "gifted children are superior in all developmental areas" will result in the aggravation of both academic and social-emotional problems in these children. This study attempts to provide foresight on these issues through a case study on Ruzgar, a potentially gifted 5 years and 3 months-old male child. As a result of this evaluation, Ruzgar was found to have exceptional skills in both language and cognitive areas, while having delayed development and a need for support in social-emotional areas. Following this period of evaluation, Ruzgar was found to exhibit asynchronous development particularly in social-emotional development areas. Possible topics of focus for subsequent work include different screening methods for early detection and intervention for asynchronous development as well as the development of enriched activities to address differences in developmental speeds of young gifted children. Apart from these, another topic that has not yet received sufficient attention is the development of educational programs for parents of gifted children focusing on how they can deal with asynchronous development and associated problems. Finally, it is equally important to develop and characterize the effectiveness of programs to guide and educate teachers so that they can properly and correctly interpret differences in developmental differences they observe in their students. 